\title{
Comparative evaluation of cashew nut shelling machines
}

\author{
R.V. POWAR, V.V. AWARE, A.A. DEOGIRIKAR, S.V. AWARE AND P.U. SHAHARE
}

Received : 04.05.2017; Revised : 01.09.2017; Accepted : 16.09.2017

See end of the Paper for authors' affiliation

Correspondence to :

\section{R.V. POWAR}

Department of Farm Machinery and Power, College of Agricultural Engineering and Technology, Dr. Balasaheb Sawant Kokan Krishi Vidyapeeth Dapoli, RATNAGIRI (M.S.) INDIA Email : ranjitpowar56@gmail. com
- ABSTRACT : The study highlights the performance of different shelling machines used in Kokan region of Maharashtra. The effect of cashew nut size on performance of cashew nut shelling machines and there comparative differences between three shelling machines were studied. It was found that, the size of cashew nut had significant effect on the shelling efficiency of machine. The per cent shelling efficiency of the machine increased with increase in size of cashew nut. The manual operated shelling machine showed higher shelling efficiency as compared to traditional and improved power operated shelling machine. It is also observed that the improved power operated machine had lower uncut, breakage, higher whole kernel recovery and cashew nut picking efficiency as compared with traditional power operated and manual shelling machine. Operating cost of manual, traditional and improved power operated cashew nut shelling machine were $7,3.12$ and $2.31 \mathrm{Rs} . / \mathrm{kg}$, respectively. Operating cost of improved shelling machine was 66 per cent and 57.4 per cent higher as compared to manual and traditional power operated shelling machine, respectively. Improved power operated shelling machine saved monthly Rs. 21138/- as compared to manually operate shelling machine.

- KEY WORDS : Cashew nut, Shelling machines, Efficiency, Operating cost

-HOW TO CITE THIS PAPER : Powar, R.V., Aware, V.V., Deogirikar, A.A., Aware, S.V. and Shahare, P.U. (2017). Comparative evaluation of cashew nut shelling machines. Internat. J. Agric. Engg., 10(2) : 570-576, DOI: 10.15740/HAS/IJAE/10.2/570-576. 